\title{
Assessing Anxiety, Depression and Quality of Life in Patients with Peripheral Facial Palsy: A Systematic Review
}

\author{
Ferran Cuenca-Martínez ${ }^{1,2}$, Eva Zapardiel-Sánchez ${ }^{1}{ }$, Enrique Carrasco-González ${ }^{1}$, Roy La Touche ${ }^{\text {Corresp., } 1,2,3}{ }^{\text {, Luis }}$ \\ Suso-Martí ${ }^{2,4}$ \\ ${ }^{1}$ Departamento de Fisioterapia. Centro Superior de Estudios Universitarios La Salle, Universidad Autónoma de Madrid, Madrid, Spain \\ Motion in Brains Research Group, Institute of Neuroscience and Sciences of the Movement (INCIMOV), Centro Superior de Estudios Universitarios La \\ Salle, Universidad Autónoma de Madrid, Spain., Madrid, Spain \\ 3 Instituto de Neurociencia y Dolor Craneofacial (INDCRAN), Madrid, Spain \\ 4 Universidad CEU Cardenal Herrera, Valencia, Spain \\ Corresponding Author: Roy La Touche \\ Email address: roylatouche@yahoo.es
}

Objective: Peripheral facial palsy (PFP) is predominantly a unilateral disorder of the facial nerve , which can lead to psychological disorders that can result in decreased quality of life. The aim of this systematic review was to assess anxiety, depression and quality of life symptoms associated with PFP.

Data sources: We searched the Medline, PEDro, CINAHL and Google Scholar databases to conduct this systematic review while following Preferred Reporting Items for Systematic Reviews and Meta-Analyses standards. The search was performed by two independent reviewers, and differences between the two reviewers were resolved by consensus.

Study Selection: The search terms used were derived from the combination of the following MeSH terms: "facial paralysis", "bell palsy", "anxiety", "anxiety disorders", "depression", "depressive disorders", "quality of life" and not MeSH: "facial palsy", "hemifacial paralysis", "facial paresis", "Peripheral Facial Paralysis", using the combination of different Boolean operators (AND/OR).

Data Extraction: On November $1^{\text {st }}(2019)$.

Data Synthesis: In total, 18 cross-sectional articles and two case-control studies were selected.

Conclusions: The cross-sectional articles showed low methodological quality, while the case-control studies showed acceptable methodological quality. Limited evidence suggests that patients with PFP might have increased levels of anxiety and depressive symptoms. A qualitative analysis also showed limited evidence that quality of life might be diminished in patients with PFP.

PROSPERO: CRD42020159843 
1 Assessing Anxiety, Depression and Quality of Life in Patients with Peripheral Facial Palsy:

2 A Systematic Review

3 Psychological factors in PFP

4

5 Ferran Cuenca-Martínez ${ }^{\mathrm{a}, \mathrm{b}}$, Eva Zapardiel-Sánchez ${ }^{\mathrm{a}}$, Enrique Carrasco-González ${ }^{\mathrm{a}}$, Roy La

6 Touche $\mathrm{a}^{\mathrm{a}, \mathrm{b}, \mathrm{c}, *}$ and Luis Suso-Martíb,d

7

a. Departamento de Fisioterapia, Centro Superior de Estudios Universitarios La Salle, Universidad Autónoma de Madrid, Spain.

b. Motion in Brains Research Group, Instituto de Neurociencias y Ciencias del Movimiento (INCIMOV), Centro Superior de Estudios Universitarios La Salle, Universidad Autónoma

c. Instituto de Neurociencia y Dolor Craneofacial (INDCRAN), Madrid, Spain

d. Department of Physiotherapy, University CEU Cardenal Herrera, CEU Universities, Valencia, Spain

*Author for Correspondence: Roy La Touche

17 Facultad de Ciencias de la Salud, Centro Superior de Estudios Universitarios La Salle, Calle La 18 Salle, nº 10, 28023 Madrid, Spain.

E-Mail: roylatouche@yahoo.es

\section{Abstract}


23 Objective: Peripheral facial palsy (PFP) is predominantly a unilateral disorder of the facial

24 nerve, which can lead to psychological disorders that can result in decreased quality of life. The

25 aim of this systematic review was to assess anxiety, depression and quality of life symptoms

26 associated with PFP. Data sources: We searched the Medline, PEDro, CINAHL and Google

27 Scholar databases to conduct this systematic review while following Preferred Reporting Items

28 for Systematic Reviews and Meta-Analyses standards. The search was performed by two

29 independent reviewers, and differences between the two reviewers were resolved by consensus.

30 Study Selection: The search terms used were derived from the combination of the following

31 MeSH terms: "facial paralysis", "bell palsy", "anxiety", "anxiety disorders", "depression",

32 "depressive disorders", "quality of life" and not MeSH: "facial palsy", "hemifacial paralysis",

33 "facial paresis", "Peripheral Facial Paralysis", using the combination of different Boolean

34 operators (AND/OR). Data Extraction: On November $1^{\text {st }}$ (2019). Data Synthesis: In total, 18

35 cross-sectional articles and two case-control studies were selected. Conclusions: The cross-

36 sectional articles showed low methodological quality, while the case-control studies showed

37 acceptable methodological quality. Limited evidence suggests that patients with PFP might have

38 increased levels of anxiety and depressive symptoms. A qualitative analysis also showed limited

39 evidence that quality of life might be diminished in patients with PFP.

40 PROSPERO: CRD42020159843

41 Key words: Peripheral facial palsy; Psychological factors; Anxiety; Depressive symptoms;

42 Quality of life. 


\section{Introduction}

46 Peripheral facial palsy (PFP) is predominantly a unilateral disorder of the facial nerve (VII

47 cranial nerve), a mixed nerve with both motor and sensory fibers, whose main function is to

48 control the facial expression muscles. In addition, specifically the chorda tympani is a uniquely

49 sensitive branch that innervates the anterior two-thirds of the tongue (Alonso Navarro et al.,

50 2005; De Diego-Sastre, Prim-Espada \& Fernández-García, 2005). However, despite being

51 predominantly a unilateral clinical entity, it has been found that PFP can also be a bilateral

52 disorder (Adour et al., 1978; Stahl \& Ferit, 1989).

53 PFP has been shown to have several etiologies, which can be classified as a) idiopathic,

54 commonly referred to as Bell's palsy; b) infectious, such as Lyme disease, otitis media or even

55 related to herpes virus like the Ramsay Hunt syndrome, which occurs by reactivation of the

56 varicella-zoster virus at the geniculate ganglion; c) genetic such as Melkersson-Rosenthal

57 syndrome or Albers-Schönberg disease; d) tumorous, e) traumatic and f) post-surgical (Herrero

58 Velázquez et al., 2009; Williams, 2010; Lorch \& Teach, 2010).

59 At the motor level, PFP is related to a loss of essential facial functions, such as blinking, nasal

60 breathing, lip sealing, smiling or speaking (Roob, Fazekas \& Hartung, 1999; Lorch \& Teach,

61 2010). Involvement of the musculature around the eyes is a key clinical finding for

62 differentiating PFP from central facial palsy although at the beginning of the course of an

63 incomplete PFP, the closing of the eyes may not be affecte (Beurskens \& Heymans, 2004). At

64 the sensory level, PFP is characterized by a diminished sense of taste (Roob, Fazekas \& Hartung,

65 1999; Lorch \& Teach, 2010).

66 PFP can lead to psychosocial disorders such as depressive symptoms, high anxiety levels and

67 reduced quality of life. Changes in facial symmetry can lead to depressed mood, which has 
68 previously been associated with maladaptive behavior and depressive symptoms (Macgregor,

69 1990; Valente, 2004). The facial expressions of patients with PFP are often perceived negatively

70 by observers, even when the patients are smiling (Ishii et al., 2012). Norris et al. (2019) showed

71 that patients with PFP reported a decline in psychological wellbeing due to their perceived

72 appearance and healthcare experience. Further research is therefore needed to relate the

73 functional disorders of PFP to the possible psychosocial effects that aesthetic changes can have

74 on this type of patient. Greater knowledge in this regard could increase the therapeutic efficacy

75 of treatments and the quality of life of patients with PFP.

76 The main objective of this systematic review was to evaluate the involvement of psychological

77 variables such as anxiety, depressive symptoms and quality of life in patients with PFP.

\section{Material and Methods}

79 The present systematic review study was conducted with the defined protocol and subdivided

80 into four phases based on the standards of the Preferred Reporting Items for Systematic Reviews

81 and Meta-Analyses statement (Fig. 1) (Moher et al., 2009). The protocol of this systematic

82 review was registered in an international register prior to starting the article (PROSPERO,

83 CRD42020159843).

\section{Inclusion criteria}

85 The studies included in this systematic review had to meet the following criteria: a) cross-

86 sectional, cohort or case-control study with a methodological design; b) patients with PFP; and c)

87 evaluating only the following variables: anxiety, depression and quality of life.

\section{Search strategy}

89 The systematic search of the included articles was conducted on the following databases:

90 MEDLINE (from 1950 to November 2019), CINAHL (from 1982 to November 2019), PEDro 
91 (from 1950 to November 2019) and Google Scholar carried out in the latter on November $1^{\text {st }}$,

92 2019. The search terms used were derived from the combination of the following MeSH terms:

93 "facial paralysis", "bell palsy", "anxiety", "anxiety disorders", "depression", "depressive

94 disorders", "quality of life", and not MeSH: "facial palsy", "hemifacial paralysis", "facial

95 paresis", "Peripheral Facial Paralysis", using the combination of different Boolean operators

96 (AND/OR). We used the study design type (observational studies) as a filter.

97 Two independent reviewers (RLT and FCM) performed the search using the same methodology.

98 Differences between the two reviewers were resolved by consensus.

\section{Selection criteria and data extraction}

100 Two independent reviewers (EZS and ECG) conducted the first evaluation of the studies to 101 assess the relevance (or lack thereof) of the systematic review. The reviewers used the articles'

102 title, abstract and keywords for this initial screening process. If there was no initial consensus or 103 the information provided by the abstract contained insufficient information, the full text was 104 reviewed.

105 The full text was then reviewed to ensure that the studies met the inclusion criteria. A third 106 reviewer (LSM) measured when there were differences between the evaluators until a consensus 107 was reached. The data were extracted using a structured protocol that ensured that the most 108 relevant information was obtained from each study.

\section{Methodological quality assessment}

110 The methodological quality of the articles included in this review was assessed using the

111 Newcastle-Ottawa modified quality assessment scale (NOS) (Deeks et al., 2003). NOS is an

112 appropriate tool for assessing the quality of case control, cohort and cross-sectional studies and

113 has moderate interexaminer reliability (Hootman et al., 2011). NOS consists of 3 criteria with a 
114 minimum of 0 stars and a maximum of 4: participant selection, exposure evaluation, results and

115 comparability. In the total star count, each study is rated as one of the following categories: 1)

116 poor, 0-3 stars; 2) acceptable, 4-5 stars; 3) good, 6-7 stars; and 4) excellent, 8-9 stars.(Wells et

117 al., 2015) For the cross-sectional studies, we employed the modified version proposed by

118 Fingleton et al. (2015) in which 1) 0-1 out of a possible 3 stars is considered poor quality, 2) 2

119 out of 3 is considered acceptable quality and 3) 3 out of 3 is considered good quality.

120 Two independent evaluators (EZS and ECG) reviewed and examined the methodological quality

121 of the studies included in the present study, and disagreements were resolved by consensus

122 through the mediation of a third evaluator (FCM). Interevaluator reliability was determined using

123 the kappa ( $\kappa)$ coefficient, where 1) $\kappa>0.7$ indicated a high level of interevaluator agreement, 2)

$124 \kappa=0.5-0.7$ indicated moderate interevaluator agreement, and 3) $\kappa<0.5$ indicated low

125 interevaluator agreement (Cohen, 1960).

\section{Qualitative analysis}

127 For the qualitative analysis of the selected studies, we used an adaptation of the classification 128 criteria proposed by van Tulder et al. for randomized clinical trials adapted for cross-sectional 129 observational, cohort and case-control studies (van Tulder et al., 2003). The results were divided 130 into five levels depending on the methodological quality: 1) strong evidence, representing results 131 from multiple studies (at least three studies); 2) moderate evidence, representing results from 132 multiple low-quality studies and/or one high-quality study; 3) limited evidence, one case-control 133 and/or low-quality cohort study and/or at least two cross-sectional studies; and 4) conflicting 134 evidence, inconsistent findings across multiple studies (at least three studies), and 5) No 135 evidence, where there are no studies of any kind for an outcome category.

\section{Results}


137 We selected 18 cross-sectional studies (Weir et al., 1995; VanSwearingen et al., 1998;

138 VanSwearingen, Cohn \& Bajaj-Luthra, 1999; Coulson et al., 2004; Bradbury, Simons \& Sanders,

139 2006; Lee et al., 2007; Fu, Bundy \& Sadiq, 2011; Walker et al., 2012; Pouwels et al., 2014;

140 Lindsay, Bhama \& Hadlock, 2014; Sun et al., 2015; Kleiss et al., 2015; Togni et al., 2016; Volk

141 et al., 2017; Nellis et al., 2017; Worrack et al., 2018; Díaz-Aristizabal et al., 2019; Muhammad

142 Kassim, Abdullahi \& Sammani Usman, 2019) and 2 case-control studies (Silva et al., 2011;

143 Goines et al., 2016) in the first phase of the analysis. For all articles, we analyzed the variables

144 depression, anxiety and quality of life. Table 1 presents the study sample's characteristics, the

145 symptom duration, the inclusion criteria, the measures of the variables and their assessment, and

146 the conclusions of the analyzed psychological variables.

147 Characteristics of the study population

148 All studies were conducted with populations with PFP. A total of 2362 patients were evaluated,

149 with a mean age of 45.7 years (range, 14-81 years). In 9 studies, the sample consisted of more

150 women than men (Weir et al., 1995; VanSwearingen, Cohn \& Bajaj-Luthra, 1999; Bradbury,

151 Simons \& Sanders, 2006; Walker et al., 2012; Pouwels et al., 2014; Lindsay, Bhama \& Hadlock,

152 2014; Togni et al., 2016; Worrack et al., 2018; Díaz-Aristizabal et al., 2019), while two studies

153 had more men than women (Kleiss et al., 2015; Muhammad Kassim, Abdullahi \& Sammani

154 Usman, 2019).

155 Two studies (Pouwels et al., 2014; Díaz-Aristizabal et al., 2019) differentiated between patients

156 with left or right PFP. Another study (Silva et al., 2011) observed a division between different

157 phases of PFP, including a flaccid phase, a recovery phase and a sequel phase. Finally Coulson et

158 al., 2004 and Muhammad Kassim, Abdullahi \& Sammani Usman (2019) included participants

159 with unilateral lower motor neuron facial nerve paralysis. 


\section{Results of the methodological quality assessment}

161 Of the 20 articles included in this systematic review, 18 were cross-sectional observational

162

163

164

165

166

167 168

169

170

171

172

173

174

175

176

177

178

179

180

181

182

studies, and 2 were case-control studies. The 18 cross-sectional studies showed low

methodological quality (with scores of 1 out of 3 stars), while the 2 case-control studies showed acceptable methodological quality (with scores of 6 out of 9 stars). The third evaluator was needed to reach consensus on 2 of the articles. According to the kappa coefficient $(\kappa=0.736)$, agreement among the assessors was high. The modified NOS results on the quality of the crosssectional studies are presented in Table 2, while the results of the quality of the case-control studies are presented in Table 3.

\section{Qualitative analysis}

There was limited evidence that anxiety levels are higher in patients with PFP (Weir et al., 1995; Bradbury, Simons \& Sanders, 2006; Fu, Bundy \& Sadiq, 2011; Silva et al., 2011; Walker et al., 2012; Pouwels et al., 2014; Sun et al., 2015; Worrack et al., 2018; Díaz-Aristizabal et al., 2019; Muhammad Kassim, Abdullahi \& Sammani Usman, 2019). This variable was assessed with the Hospital Anxiety and Depression Scale in 6 studies (Bradbury, Simons \& Sanders, 2006; Fu, Bundy \& Sadiq, 2011; Walker et al., 2012; Pouwels et al., 2014; Díaz-Aristizabal et al., 2019; Muhammad Kassim, Abdullahi \& Sammani Usman, 2019), with the Self-reported Anxiety Scale in 1 study (Sun et al., 2015), with the General Health Questionnaire in 1 study (Weir et al., 1995), by open interview in 1 study (Silva et al., 2011) and with the Liebowitz Social Anxiety Scale in 1 study (Worrack et al., 2018).

There was limited evidence that depressive symptoms are present in patients with PFP (Weir et al., 1995; VanSwearingen et al., 1998; VanSwearingen, Cohn \& Bajaj-Luthra, 1999; Bradbury, Simons \& Sanders, 2006; Fu, Bundy \& Sadiq, 2011; Silva et al., 2011; Walker et al., 2012; 
183 Pouwels et al., 2014; Sun et al., 2015; Worrack et al., 2018; Díaz-Aristizabal et al., 2019;

184 Muhammad Kassim, Abdullahi \& Sammani Usman, 2019). One study found that impaired 185 smiling and physical disability might be the main predictors of symptoms compatible with 186 depression. Depressive symptoms was assessed with the Hospital Anxiety and Depression Scale 187 in 6 studies (Bradbury, Simons \& Sanders, 2006; Fu, Bundy \& Sadiq, 2011; Walker et al., 2012;

188 Pouwels et al., 2014; Díaz-Aristizabal et al., 2019; Muhammad Kassim, Abdullahi \& Sammani 189 Usman, 2019), with the Patient Health Questionnaire-9 in 1 study (Worrack et al., 2018), with 190 the Self-reported Depression Scale in 1 study (Sun et al., 2015), with the Beck Depression 191 Inventory in 2 studies (VanSwearingen et al., 1998; VanSwearingen, Cohn \& Bajaj-Luthra, 192 1999) with the General Health Questionnaire in 1 study (Weir et al., 1995) and by open interview 193 in 1 study (Silva et al., 2011).

194 There was limited evidence that quality of life might be reduced in patients with PFP (Lee et al., 195 2007; Lindsay, Bhama \& Hadlock, 2014; Kleiss et al., 2015; Goines et al., 2016; Nellis et al., 196 2017). Quality of life was assessed with the Facial Clinical Evaluation Scale in 2 studies (Lee et 197 al., 2007; Lindsay, Bhama \& Hadlock, 2014) with a 100-point analog scale in 1 study (Goines et 198 al., 2016), with a visual analog scale in 1 study (Nellis et al., 2017) and with the House-

199 Brackmann scale in 1 study (Kleiss et al., 2015).

\section{Discussion}

201 The main objective of this review was to analyze the involvement of psychological variables in 202 PFP. The results showed that anxiety and symptoms compatible with depression can be present 203 in patients with PFP. Quality of life can also be diminished in these patients and is related to the 204 presence of psychological factors. 
205 Psychological factors can play a role in patients with PFP for several reasons, one of which is the 206 possible involvement of facial palsy in an individual's self-concept. The functional and motor 207 disorders of the facial region present in these patients significantly affect their perception of their 208 self-image (Cross et al., 2000). This perception of physical attributes and self-image (or self209 concept) significantly influences mood and self-esteem (Campbell, Assanand \& Di Paula, 2003).

210 The self-concept of patients with PFP is disrupted, in other words, there is a dissonance between 211 their perceived image (the image altered by the PFP) and their learned self-concept, which has 212 previously been associated with a decrease in self-esteem, the presence of anxiety and the 213 appearance of depressive symptoms (Campbell, Assanand \& Di Paula, 2003). Previous studies 214 have shown that patients with facial palsy have an altered visualization of the affected side and 215 that their self-concept is jeopardized, which could be related to the results of this study (Ishii et 216 al., 2011).

217 Patients with PFP routinely report psychological distress due to the negative implications of PFP 218 in social interactions. Previous studies have indicated that these patients' physical appearance 219 reduces their self-esteem and attractiveness, which, due to social stereotypes, makes them appear 220 less intelligent or confident, leading many people to avoid social relationships with patients with 221 PFP (Ishii et al., 2012). Many patients with PFP are unable to express themselves or recognize 222 facial expressions, which can also have a negative effect on their ability to communicate in their 223 social setting, accentuating their difficulties interacting with others (Korb et al., 2016).

224 These patients might therefore view social interactions negatively, leading them to limit or avoid 225 completely such interactions, resulting in social isolation, a factor highly related to poorer moods 226 and depressive symptoms (Macgregor, 1990; Ishii et al., 2016). A number of studies have shown 
227 an association between greater severity of facial palsy and greater depressive symptoms related 228 to these social aspects (Nellis et al., 2017).

229 Some types of facial palsy such as Bell's palsy have been linked to immune system responses in 230 nerve tissue. Previous research studies have shown increased proinflammatory cytokine levels in 231 patients with this disease, which has been linked as a pathogenetic factor to the origin and 232 maintenance of the disease (Yilmaz et al., 2002). Elevated anxiety and stress levels can also 233 increase inflammatory levels, which in turn can exacerbate symptoms. For example, one study

234 showed a two-way relationship between anxiety levels and Bell's palsy (Tseng et al., 2017).

235 Lastly, quality of life is related to the subjective perception of health, which includes the 236 relationship between physical and mental health, as well as functionality. Quality of life 237 therefore includes individual satisfaction with the state of health and the emotional response 238 associated with it. Therefore, the aspects mentioned above can have a significant influence on the 239 quality of life of patients with PFP (Taşkapilioğlu \& Karli, 2013). Our results show that the 240 quality of life can be diminished in these patients and that their perception is closely linked to the 241 psychological factors mentioned above. These results are similar to those obtained for other 242 clinical entities such as temporomandibular disorders (Trize et al., 2018) and chronic migraine 243 (Fernández-Concepción \& Canuet-Delis, 2003).

244 From a clinical point of view, the results of the present review emphasize the need to thoroughly 245 assess psychological aspects such as anxiety and depressive symptoms in patients with PFP. The 246 correct management of these factors from a biopsychosocial paradigm can have a major impact 247 on therapeutic success and an increase in the patients' quality of life.

\section{$248 \quad$ Limitations}


249 There are several limitations to be considered when interpreting the results of this systematic

250 review. Firstly, the main limitation to be considered is the heterogeneity of the sample included

251 in this article. It is very complicated to draw solid conclusions when you include patients with

252 different states, moments and durations of PFP. For example, both Bradbury et al. (2006) and

253 Coulson et al. (2004) include patients with PFP lasting at least one year. The work carried out by

254 Diaz-Arastizabal et al. (2019) includes patients with PFP between 6 and 752 months. Fu et al.

255 older than 6 months. Lee et al. (2007) deals with patients with PFP secondary to surgery, same as

256 Sun et al. (2015), and with at least 24 months of duration, Lindsay et al. (2014) includes flaccid

257 PFP or Silva et al. (2011) had a sample containing patients with PFP in the flaccid phase, another

258 sample in the recovery phase and another in the sequelae phase. This limitation is very important

259 to consider because the conclusions are established using the whole of this very heterogeneous

260 sample. The results must therefore be considered with great caution. This fact also makes it

261 impossible to carry out a statistical aggregation. Secondly, probably a greater number of

262 psychological variables would have provided more information and could be considered a

263 limitation. Thirdly, a number of the studies presented a high risk of bias due to their

264 methodological quality or limited sample sizes, which could affect the results. Finally, the low

265 number of articles could also be considered a limitation due to the impossibility of performing a

266 meta-analysis or only because of the difficulty in drawing solid conclusions.

\section{Conclusions}

268 The results of this systematic review showed that patients with PFP can have increased anxiety

269 levels and depressive symptoms, as well as having a decrease of quality of life. The quality of

270 evidence of all outcome measures was limited. It is therefore that the presence of these

271 psychological variables in patients with PFP should be considered clinically. However, the 
272 authors stress the heterogeneity of the sample and therefore the findings should be taken with

273 caution.

274 Author Disclosure Statement

275 No competing financial interests exist.

276 Funding Information

277 No funding was received for this article.

278 Acknowledgements

279 The authors would like to thank Centro Superior de Estudios Universitarios CSEU La Salle for 280 its services in editing this manuscript.

281 


\section{References}

284 Adour KK, Byl FM, Hilsinger RL, Kahn ZM, Sheldon MI. 1978. The true nature of Bell's palsy:

285 analysis of 1,000 consecutive patients. The Laryngoscope 88:787-801. DOI:

$286 \quad$ 10.1002/lary.1978.88.5.787.

287 Alonso Navarro H, Zurdo Hernández JM, Ortí Pareja M, Jiménez Jiménez FJ. 2005. Parálisis

288 facial periférica recurrente familiar. Revista de Neurología 40:61. DOI:

$289 \quad 10.33588 / \mathrm{rn} .4001 .2004565$.

290 Beurskens CHG, Heymans PG. 2004. Physiotherapy in patients with facial nerve paresis:

291 Description of outcomes. American Journal of Otolaryngology - Head and Neck Medicine

292 and Surgery 25:394-400. DOI: 10.1016/j.amjoto.2004.04.010.

293 Bradbury ET, Simons W, Sanders R. 2006. Psychological and social factors in reconstructive 294 surgery for hemi-facial palsy. Journal of Plastic, Reconstructive and Aesthetic Surgery 59:272-278. DOI: 10.1016/j.bjps.2005.09.003.

296

Campbell JD, Assanand S, Di Paula A. 2003. The structure of the self-concept and its relation to 297 298

299

300 psychological adjustment. Journal of personality 71:115-40. DOI: 10.1111/1467-6494.t01$1-00002$

Cohen J. 1960. A Coefficient of Agreement for Nominal Scales. Educational and Psychological

301 Coulson SE, O’Dwyer NJ, Adams RD, Croxson GR. 2004. Expression of emotion and quality of 302 life after facial nerve paralysis. Otology and Neurotology 25:1014-1019. DOI:

303 10.1097/00129492-200411000-00026.

304 Cross T, Sheard CE, Garrud P, Nikolopoulos TP, O’Donoghue GM. 2000. Impact of facial paralysis on patients with acoustic neuroma. The Laryngoscope 110:1539-42. DOI: 
307

308

309

310

311

312

313

314

315

Deeks JJ, Dinnes J, D’Amico R, Sowden AJ, Sakarovitch C, Song F, Petticrew M, Altman DG. 2003. Evaluating non-randomised intervention studies. Health Technology Assessment 7. DOI: $10.3310 /$ hta 7270 .

Díaz-Aristizabal U, Valdés-Vilches M, Fernández-Ferreras TR, Calero-Muñoz E, BienzobasAllué E, Moracén-Naranjo T. 2019. Correlations between impairment, psychological distress, disability, and quality of life in peripheral facial palsy. Neurologia 34:423-428. DOI: 10.1016/j.nrl.2017.03.004.

De Diego-Sastre JI, Prim-Espada MP, Fernández-García F. 2005. Epidemiología de la parálisis facial del Bell. Revista de neurologia 41:287-90. DOI: 10.33588/rn.4105.2004593.

Fernández-Concepción O, Canuet-Delis L. 2003. [Disability and quality of life in patients with migraine: determining factors]. Revista de neurologia 36:1105-12.

Fingleton C, Smart K, Moloney N, Fullen BM, Doody C. 2015. Pain sensitization in people with knee osteoarthritis: a systematic review and meta-analysis. Osteoarthritis and Cartilage 23:1043-1056. DOI: 10.1016/j.joca.2015.02.163.

Fu L, Bundy C, Sadiq SA. 2011. Psychological distress in people with disfigurement from facial palsy. Eye 25:1322-1326. DOI: 10.1038/eye.2011.158.

Goines JB, Ishii LE, Dey JK, Phillis M, Byrne PJ, Boahene KDO, Ishii M. 2016. Association of facial paralysis-related disability with patient- and observer-perceived quality of life. JAMA Facial Plastic Surgery 18:363-369. DOI: 10.1001/jamafacial.2016.0483.

Herrero Velázquez S, Guerrero Peral ÁL, Fuertes JJ, Rojo Martínez E, Peñas Martínez ML, Cortijo García E, Fernández Herranz R. 2009. Neuralgia del nervio intermediario y parálisis facial con o sin herpes. Revista de Neurología 49:670. DOI: 10.33588/rn.4912.2009233. 
329 Hootman JM, Driban JB, Sitler MR, Harris KP, Cattano NM. 2011. Reliability and validity of 330 three quality rating instruments for systematic reviews of observational studies. Research 331 Synthesis Methods 2:110-118. DOI: 10.1002/jrsm.41.

332 Ishii L, Dey J, Boahene KDO, Byrne PJ, Ishii M. 2016. The social distraction of facial paralysis: 333 Objective measurement of social attention using eye-tracking. The Laryngoscope 126:334334 9. DOI: $10.1002 /$ lary.25324.

335

336

337

338

339

340

341

342

343

344

345

346

347

348

349

350

351

Ishii LE, Godoy A, Encarnacion CO, Byrne PJ, Boahene KDO, Ishii M. 2011. What faces reveal: impaired affect display in facial paralysis. The Laryngoscope 121:1138-43. DOI: 10.1002/lary.21764.

Ishii L, Godoy A, Encarnacion CO, Byrne PJ, Boahene KDO, Ishii M. 2012. Not just another face in the crowd: Society's perceptions of facial paralysis. Laryngoscope 122:533-538. DOI: $10.1002 /$ lary.22481.

Kleiss IJ, Hohman MH, Susarla SM, Marres HAM, Hadlock TA. 2015. Health-related quality of life in 794 patients with a peripheral facial palsy using the FaCE Scale: A retrospective cohort study. Clinical Otolaryngology 40:651-656. DOI: 10.1111/coa.12434.

Korb S, Wood A, Banks CA, Agoulnik D, Hadlock TA, Niedenthal PM. 2016. Asymmetry of Facial Mimicry and Emotion Perception in Patients With Unilateral Facial Paralysis. JAMA facial plastic surgery 18:222-7. DOI: 10.1001/jamafacial.2015.2347.

Lee J, Fung K, Lownie SP, Parnes LS. 2007. Assessing impairment and disability of facial paralysis in patients with vestibular schwannoma. Archives of Otolaryngology - Head and Neck Surgery 133:56-60. DOI: 10.1001/archotol.133.1.56.

Lindsay RW, Bhama P, Hadlock TA. 2014. Quality-of-life improvement after free gracilis muscle transfer for smile restoration in patients with facial paralysis. JAMA Facial Plastic 
Surgery 16:419-424. DOI: 10.1001/jamafacial.2014.679.

353 Lorch M, Teach SJ. 2010. Facial nerve palsy: Etiology and approach to diagnosis and treatment. 354 Pediatric Emergency Care 26:763-769. DOI: 10.1097/PEC.0b013e3181f3bd4a.

355 Macgregor FC. 1990. Facial disfigurement: problems and management of social interaction and 356 implications for mental health. Aesthetic plastic surgery 14:249-57. DOI: 10.1007/bf01578358.

358

359

360

361

362

363

364

365

366

367

368

369

370

371

372

373

374

Moher D, Liberati A, Tetzlaff J, Altman DG. 2009. Preferred reporting items for systematic reviews and meta-analyses: the PRISMA statement. Int J Surg 8:6. DOI: 10.1016/j.ijsu.2010.02.007.

Muhammad Kassim N, Abdullahi A, Sammani Usman J. 2019. Relationship Between Psychological Symptoms, Age, Severity of Symptoms, and Societal Integration in Patients With Facial Nerve Paralysis. Iranian Rehabilitation Journal:235-240. DOI:

10.32598/irj.17.3.235.

Nellis JC, Ishii M, Byrne PJ, Boahene KDO, Dey JK, Ishii LE. 2017. Association among facial paralysis, depression, and quality of life in facial plastic surgery patients. JAMA Facial Plastic Surgery 19:190-196. DOI: 10.1001/jamafacial.2016.1462.

Norris JH, Longmire NM, Kilcoyne S, Johnson D, Fitzpatrick R, Klassen AF. 2019. Exploring Patient Experience of Facial Nerve Palsy to Inform the Development of a PROM. Plastic and reconstructive surgery. Global open 7:e2072. DOI: 10.1097/GOX.0000000000002072.

Pouwels S, Ingels K, Van Heerbeek N, Beurskens C. 2014. Cosmetic appreciation of lateralization of peripheral facial palsy: "Preference for left or right, true or mirror image?" European Archives of Oto-Rhino-Laryngology 271:2517-2521. DOI: 10.1007/s00405-013$2790-8$ 
375 Roob G, Fazekas F, Hartung H-P. 1999. Peripheral Facial Palsy: Etiology, Diagnosis and 376 Treatment. European Neurology 41:3-9. DOI: 10.1159/000007990.

377 Silva MFF, Cunha MC, Lazarini PR, Fouquet ML. 2011. Conteúdos psíquicos e efeitos sociais 378 associados à paralisia facial periférica: abordagem fonoaudiológica. International Archives 379 of Otorhinolaryngology 15:450-460. DOI: 10.1590/s1809-48722011000400008.

380 Stahl N, Ferit T. 1989. Recurrent bilateral peripheral facial palsy. Journal of Laryngology and 381 Otology 103:117-119. DOI: 10.1017/S0022215100108199.

382 Sun D, Shi Z, Li P, Shi S, Cai Y. 2015. Psychological status and quality of life in acoustic 383 neuroma patients with facial palsy after microsurgery: a 1-year postoperative follow-up 384 study. Acta Neurologica Belgica 115:311-316. DOI: 10.1007/s13760-014-0382-z. 385 386 387 388 389 390 391 392 393 394 395 396 397

Taşkapilioğlu Ö, Karli N. 2013. Assessment of Quality of Life in Migraine. Noro psikiyatri arsivi 50:S60-S64. DOI: 10.4274/Npa.y7310.

Togni R, Abbamonte M, Comelli M, Mandrini S, Dall'angelo A, Pavese C, De Bernardi E, Mariani F, Sala V, Caverzasi E, Giorgi I, Carlisi E, Dalla Toffola E. 2016. Personality Traits and Perception of Disability after Facial Palsy. J Psychol Psychother 6:276. DOI: 10.4172/2161-0487.1000276.

Trize D de M, Calabria MP, Franzolin S de OB, Cunha CO, Marta SN. 2018. Is quality of life affected by temporomandibular disorders? Einstein (Sao Paulo, Brazil) 16:eAO4339. DOI: 10.31744/einstein_journal/2018AO4339.

Tseng C-C, Hu L-Y, Liu M-E, Yang AC, Shen C-C, Tsai S-J. 2017. Bidirectional association between Bell's palsy and anxiety disorders: A nationwide population-based retrospective cohort study. Journal of Affective Disorders 215:269-273. DOI:

10.1016/J.JAD.2017.03.051. 
398 van Tulder M, Furlan A, Bombardier C, Bouter L. 2003. Updated Method Guidelines for 399 Systematic Reviews in the Cochrane Collaboration Back Review Group. Spine 28:12901299. DOI: 10.1097/01.brs.0000065484.95996.af.

401 Valente SM. 2004. Visual disfigurement and depression. Plastic surgical nursing : official 402 journal of the American Society of Plastic and Reconstructive Surgical Nurses 24:140-6; 403 quiz 147-8. DOI: 10.1097/00006527-200410000-00003.

404 VanSwearingen JM, Cohn JF, Bajaj-Luthra A. 1999. Specific impairment of smiling increases 405 the severity of depressive symptoms in patients with facial neuromuscular disorders. $406 \quad$ Aesthetic Plastic Surgery 23:416-423. DOI: 10.1007/s002669900312.

407 VanSwearingen JM, Cohn JF, Turnbull J, Mrzai T, Johnson P. 1998. Psychological distress:

408 Linking impairment with disability in facial neuromotor disorders. Otolaryngology - Head 409 and Neck Surgery 118:790-796. DOI: 10.1016/S0194-5998(98)70270-0.

410 Volk GF, Granitzka T, Kreysa H, Klingner CM, Guntinas-Lichius O. 2017. Initial severity of motor and non-motor disabilities in patients with facial palsy: an assessment using patientreported outcome measures. European Archives of Oto-Rhino-Laryngology 274:45-52. DOI: $10.1007 / \mathrm{s} 00405-016-4018-1$.

414 Walker DT, Hallam MJ, Ni Mhurchadha S, Mccabe P, Nduka C. 2012. The psychosocial impact 415 of facial palsy: Our experience in one hundred and twenty six patients. Clinical $416 \quad$ Otolaryngology 37:474-477. DOI: 10.1111/coa.12026.

417 Weir A, Pentland B, Crosswaite A, Murray J, Mountain R. 1995. Bell's palsy: the effect on self418 image, mood state and social activity. Clinical Rehabilitation 9:121-125. DOI: $10.1177 / 026921559500900206$.

Wells G, Tugwell P, O’Connell D, Welch V, Peterson J, Shea B, Losos M. 2015. The Newcastle- 
421 Ottawa Scale (NOS) for assessing the quality of nonrandomized studies in meta-analyses.

422 Williams DS. 2010. Ramsay Hunt syndrome. Journal of insurance medicine (New York, N.Y.) 423 42:41-43. DOI: 10.17245/jdapm.2018.18.6.333.

424 Worrack S, Guntinas-Lichius O, Volk GF, Kaczmarek MC, Mühleck J, Brenk-Franz K, Strau 425 BM, Altmann U. 2018. Restricted sleep as a secondary psychosocial consequence of facial 426 palsy. Laryngo- Rhino- Otologie 97:398-404. DOI: 10.1055/a-0573-2119.

427 Yilmaz M, Tarakcioglu M, Bayazit N, Bayazit YA, Namiduru M, Kanlikama M. 2002. Serum 428 cytokine levels in Bell's palsy. Journal of the neurological sciences 197:69-72. DOI:

$429 \quad 10.1016 / \mathrm{s} 0022-510 x(02) 00049-7$.

430 
Figure 1

Prisma flow chart. 
Figura 1. PRISMA Flowchart
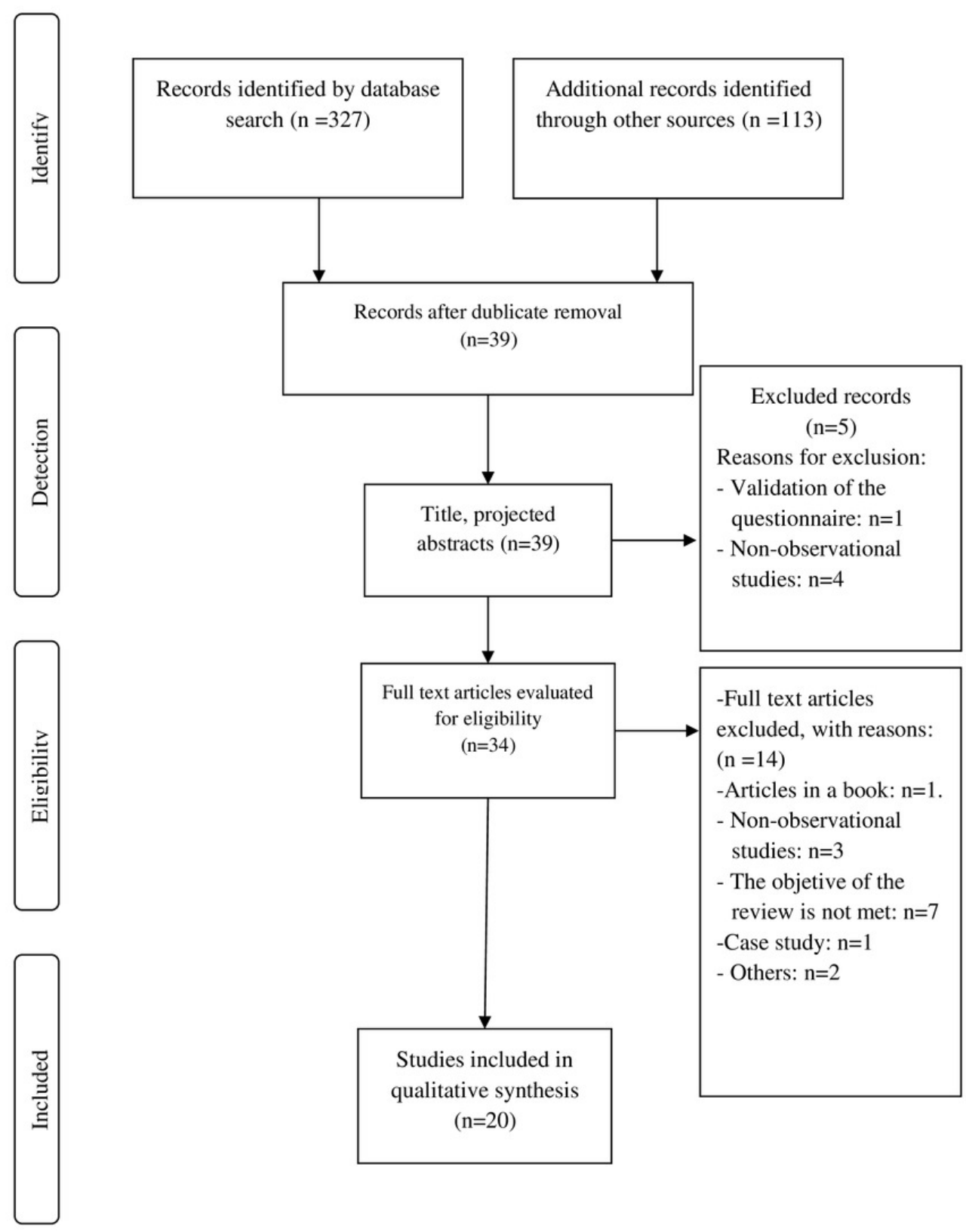


\section{Table $\mathbf{1}$ (on next page)}

Characteristics of the studies included.

PFP: peripheral facial paralysis; M: man; W: woman; SD: standard deviation; FGS: Sunnybrook Facial Grading System; HADS: Hospital Anxiety and Depression Scale; FDI: Facial Disability Index; FaCE: Facial Clinimetric Evaluation; FPEM: Facial Paralysis Evaluation Profile; GBI: Glasgow Befefit Inventory; IPQ-R: Illness Perception Questionnaire-Revised; HBS: HouseBrackmann Scale; BDI: Beck Depression Inventory; FAIR: Facial Nerve Palsy Integration Register; VAS = Visual Analogue Scale; TCI: Temperament and Character Inventory; SAS: Self-assessment Anxiety Scale, SDS: Self-assessessed Depression Scale; ABS: Affect Balance Scale; SDS: Zung Self-Rating Depression Scale; FSI: Facial Self-Image Scale; FDQ: Funcional Disability Questionnaire; GHQ: General Health Questionnaire; MSRA: Measerement of Facial Motion; LSAS: Liebowitz Social Anxiety Scale; PHQ9: Patient Health Questionaire. 
1 Table 1. Characteristics of the studies included.

\begin{tabular}{|c|c|c|c|c|c|c|c|c|}
\hline Article & Design & $\begin{array}{l}\text { Characteristics } \\
\text { of the sample } \\
\text { of PFP group }\end{array}$ & $\begin{array}{l}\text { Character } \\
\text { istics of } \\
\text { the } \\
\text { sample of } \\
\text { control } \\
\text { group }\end{array}$ & $\begin{array}{c}\text { Average } \\
\text { duration of } \\
\text { the symptoms } \\
\text { in PFP group }\end{array}$ & $\begin{array}{l}\text { Inclusion criteria in } \\
\text { PFP group }\end{array}$ & $\begin{array}{l}\text { Outcome } \\
\text { measures }\end{array}$ & $\begin{array}{l}\text { Measureme } \\
\text { nts } \\
\text { instruments }\end{array}$ & $\begin{array}{l}\text { General conclusions on } \\
\text { psychological variables }\end{array}$ \\
\hline $\begin{array}{l}\text { Díaz- } \\
\text { Aristizabal et } \\
\text { al. (2019) }\end{array}$ & $\begin{array}{l}\text { Cross- } \\
\text { sectional } \\
\text { study }\end{array}$ & $\begin{array}{c}\mathrm{N}=30 \\
7(\mathrm{M}) ; 23(\mathrm{~W}) \\
\text { Age: } 51,1(\mathrm{SD}= \\
16,02) \\
\text { Affectation: } 12 \\
\text { left; } 18 \text { right }\end{array}$ & - & - & $\begin{array}{l}\text { Over } 18 \text { years old, } \\
\text { minimum evaluation } \\
\text { time of } 6 \text { month since } \\
\text { the injury, incomplete } \\
\text { resolution of the PFP } \\
\text { and collaboration in } \\
\text { the completion of the } \\
\text { questionnaires. }\end{array}$ & $\begin{array}{l}\text { Degree of PFP } \\
\text { deficiency: } \\
\text { FGS. } \\
\text { Paralysis } \\
\text { disability: } \\
\text { FDI. } \\
\text { Quality of life } \\
\text { for patients } \\
\text { with PFP. }\end{array}$ & $\begin{array}{l}\text { Anxiety and } \\
\text { depressive } \\
\text { symptoms: } \\
\text { HADS. }\end{array}$ & $\begin{array}{l}\text { Patients with PFP with higher } \\
\text { deficits had greater physical and } \\
\text { overall disability and a worse } \\
\text { quality of life. However, they } \\
\text { did not show greater social } \\
\text { disability, nor greater } \\
\text { psychological impairment in the } \\
\text { form of anxiety and depressive } \\
\text { symptoms. } \\
\text { Patients with greater physical, } \\
\text { social and global disability had } \\
\text { greater psychological } \\
\text { impairment (anxiety and } \\
\text { depressive symptoms) and a } \\
\text { worse quality of life. }\end{array}$ \\
\hline $\begin{array}{l}\text { Bradbury et } \\
\text { al. (2006) }\end{array}$ & $\begin{array}{l}\text { Cross- } \\
\text { sectional } \\
\text { study }\end{array}$ & $\begin{array}{c}\mathrm{N}=106 \\
\text { Age: } 44,7 \\
34(\mathrm{M}) ; 72(\mathrm{~W}) \\
\text { Form of PFP: } 71 \\
\text { aquired } \\
\text { paralysis; } 35 \\
\text { congenital } \\
\text { paralysis }\end{array}$ & - & $\begin{array}{l}\text { At least } 12 \\
\text { months after } \\
\text { the operation }\end{array}$ & $\begin{array}{l}\text { Patients undergoing } \\
\text { vascularized muscle } \\
\text { graft reconstruction } \\
\text { to correct PFP. The } \\
\text { operations had been } \\
\text { performed by the } \\
\text { same surgeon and the } \\
\text { patients were taken } \\
\text { from a database at the } \\
\text { same hospital. }\end{array}$ & - & $\begin{array}{c}\text { Anxiety and } \\
\text { depressive } \\
\text { symptoms: } \\
\text { HADS. } \\
\text { Satisfaction } \\
\text { degree after } \\
\text { PFP: FPEM } \\
\text { Other } \\
\text { psychosocial } \\
\text { variables: } \\
\text { semi- } \\
\text { structured } \\
\text { interview }\end{array}$ & $\begin{array}{l}\text { There is no relationship between } \\
\text { dissatisfaction with surgery and } \\
\text { anxiety; however, this } \\
\text { relationship does occur with } \\
\text { depression. } \\
\text { Most reported feeling social } \\
\text { pressure and distress about their } \\
\text { condition. } \\
\text { Participants with consistent } \\
\text { patterns of avoidance and social } \\
\text { isolation, both before and after } \\
\text { surgery, were more likely to be } \\
\text { depressed than the rest of the } \\
\text { study group and more likely to } \\
\text { be dissatisfied with the surgery. }\end{array}$ \\
\hline Coulson et al. & Cross- & $\mathrm{N}=24$ & $\mathrm{~N}=24$ & 1 year & - & Degree of PFP & Difficulties & A movement deficit associated \\
\hline
\end{tabular}




\begin{tabular}{|c|c|c|c|c|c|c|c|c|}
\hline (2004) & $\begin{array}{l}\text { sectional } \\
\text { study }\end{array}$ & $\begin{array}{c}10(\mathrm{M}) ; 14(\mathrm{H}) \\
\text { Age: } 46,1\end{array}$ & $\begin{array}{l}17 \\
\text { couples, } 5 \\
\text { family } \\
\text { members, } \\
2 \text { friends }\end{array}$ & $\begin{array}{c}\text { Mean age: } \\
38,7\end{array}$ & & $\begin{array}{c}\text { deficiency: } \\
\text { Sunnybrook } \\
\text { Facial Grading } \\
\text { System, } \\
\text { Sydney Facial } \\
\text { Grading } \\
\text { System, HBS. } \\
\text { Quality of life: } \\
\text { SF-36 } \\
\text { PFP disability: } \\
\text { FDI. } \\
\text { Quality of life } \\
\text { after surgery: } \\
\text { GBI. }\end{array}$ & $\begin{array}{l}\text { in facial } \\
\text { expression } \\
\text { of emotions: } \\
\text { questionnair } \\
\quad \mathrm{e}\end{array}$ & $\begin{array}{l}\text { with the expression of specific } \\
\text { emotions and a decrease in } \\
\text { quality of life was identified in } \\
\text { patients with long-term PFP. }\end{array}$ \\
\hline $\begin{array}{l}\text { Fu et al. } \\
\text { (2011) }\end{array}$ & $\begin{array}{l}\text { Cross- } \\
\text { sectional } \\
\text { study }\end{array}$ & $\begin{array}{c}\mathrm{N}=103 \\
\text { Age: } 59(\mathrm{SD}= \\
17)\end{array}$ & - & $\begin{array}{l}6 \text { months }-50 \\
\text { years since } \\
\text { PFP diagnosis }\end{array}$ & $\begin{array}{c}\text { Patients with a } \\
\text { diagnosis of PFP, } \\
\text { adequate level of } \\
\text { English, PFP longer } \\
\text { than } 6 \text { months, over } \\
18 \text { years old }\end{array}$ & $\begin{array}{c}\text { Degree of PFP } \\
\text { deficiency: } \\
\text { HBS } \\
\text { Disease } \\
\text { beliefs: IPQ- } \\
\text { R. }\end{array}$ & $\begin{array}{l}\text { Anxiety and } \\
\text { depressive } \\
\text { symptoms: } \\
\text { HADS. }\end{array}$ & $\begin{array}{c}\text { Participants have a significant } \\
\text { level of psychological distress, } \\
\text { which in turn is significantly } \\
\text { related to perceptions about } \\
\text { their FP. Significant differences } \\
\text { were found between the levels } \\
\text { of anxiety among women and } \\
\text { men. }\end{array}$ \\
\hline $\begin{array}{l}\text { Muhammad } \\
\text { Kassim et al. } \\
\text { (2019) }\end{array}$ & $\begin{array}{l}\text { Cross- } \\
\text { sectional } \\
\text { study }\end{array}$ & $\begin{array}{c}\mathrm{N}=37 \\
16(\mathrm{M}) ; 21(\mathrm{~W}) \\
\text { Age: } 14-70\end{array}$ & - & - & $\begin{array}{c}\text { Patients with } \\
\text { unilateral PFP over } \\
18 \text { years old with } \\
\text { good cognitive ability } \\
\text { (more than } 24 \text { points } \\
\text { in Mini-Mental State } \\
\text { Examination). }\end{array}$ & $\begin{array}{l}\text { Degree of PFP } \\
\text { deficiency: } \\
\text { HBS } \\
\text { Community } \\
\text { integration of } \\
\text { patients with } \\
\text { PFP: FAIR }\end{array}$ & $\begin{array}{l}\text { Anxiety and } \\
\text { depressive } \\
\text { symptoms: } \\
\text { HADS. }\end{array}$ & $\begin{array}{l}\text { People with PFP may suffer } \\
\text { from emotional problems such } \\
\text { as the presence of depressive } \\
\text { symptoms, social isolation and } \\
\text { self-awareness. Women and } \\
\text { older people with PFP may be } \\
\text { more vulnerable to social } \\
\text { isolation. Women may be less } \\
\text { depressed than men. }\end{array}$ \\
\hline $\begin{array}{l}\text { Nellis et al. } \\
\text { (2017) }\end{array}$ & $\begin{array}{l}\text { Cross- } \\
\text { sectional } \\
\text { study }\end{array}$ & $\begin{array}{c}\mathrm{N}=263 \\
\text { Age: } 48,8\end{array}$ & - & $\begin{array}{c}\text { PFP } \\
\text { developed } \\
\text { post-surgery. }\end{array}$ & $\begin{array}{l}\text { Patients without FP } \\
\text { that are performed a } \\
\text { facial plastic surgery. } \\
\text { Older than } 18 \text { years } \\
\text { old and speak } \\
\text { English. Are } \\
\text { excluded patients } \\
\text { with a previous facial }\end{array}$ & $\begin{array}{l}\text { Affectation } \\
\text { level of PFPa } \\
\text { PFP: HBS } \\
\text { Quality of life: } \\
\text { EVA ( } 0=\text { bad, } \\
100=\text { very } \\
\text { good }) .\end{array}$ & $\begin{array}{l}\text { Psychometri } \\
\text { c data: } \\
\text { Validated } \\
\text { formulary: } \\
\text { depression: } \\
\text { BDI. } \\
\text { Self-reported } \\
\text { attractivenes }\end{array}$ & $\begin{array}{l}\text { Depression significantly greater } \\
\text { in patients that developed PFP } \\
\text { after surgery. The also saw } \\
\text { themselves less good looking, } \\
\text { were in a worse mood and } \\
\text { presented a decrease in quality } \\
\text { of life. There were more women } \\
\text { than men depressed. }\end{array}$ \\
\hline
\end{tabular}




\begin{tabular}{|c|c|c|c|c|c|c|c|c|}
\hline & & & & & $\begin{array}{l}\text { palsy surgery, if they } \\
\text { have malignant } \\
\text { neoplasm in head or } \\
\text { neck, if had head or } \\
\text { neck surgery and if } \\
\text { couldn't fill the } \\
\text { formulary' data on } \\
\text { their own. }\end{array}$ & & $\begin{array}{c}\text { s: EVA }(0=\mathrm{I} \\
\text { see myself } \\
\text { very bad, } \\
100=\text { I see } \\
\text { myself very } \\
\text { good }) . \\
\text { General } \\
\text { mood: EVA } \\
(0=\text { very } \\
\text { bad; } 100= \\
\text { very good }) .\end{array}$ & \\
\hline $\begin{array}{l}\text { Kleiss et al. } \\
\quad(2015)\end{array}$ & $\begin{array}{l}\text { Cross- } \\
\text { sectional } \\
\text { study }\end{array}$ & $\begin{array}{c}\mathrm{N}=794 \\
40,1(\mathrm{M}) ; 59,9 \% \\
(\mathrm{~W}) \\
\text { Age: } 47(\mathrm{SD}= \\
16)\end{array}$ & - & - & $\begin{array}{l}\text { Patients with PFP. } \\
\text { Children under } 14 \\
\text { were excluded }\end{array}$ & $\begin{array}{l}\text { Affectation } \\
\text { level of PFP: } \\
\text { HBS. }\end{array}$ & $\begin{array}{l}\text { Quality of } \\
\text { life in } \\
\text { patients with } \\
\text { PFP: FaCE. }\end{array}$ & $\begin{array}{l}\text { Quality of life is more affected } \\
\text { in patients with chronic facial } \\
\text { paralysis in a psychosocial } \\
\text { level. It is also related to } \\
\text { increase of the age. }\end{array}$ \\
\hline $\begin{array}{l}\text { Volk et al. } \\
\text { (2017) }\end{array}$ & $\begin{array}{l}\text { Cross- } \\
\text { sectional } \\
\text { study }\end{array}$ & $\begin{array}{c}\mathrm{N}=256 \\
103(\mathrm{M}) ; 153 \\
(\mathrm{~W}) \\
\text { Age: } 52(\mathrm{SD}= \\
18)\end{array}$ & - & - & $\begin{array}{c}\text { Patients with } \\
\text { unilateral PFP. } \\
\text { Patients with bilateral } \\
\text { PFP were excluded as } \\
\text { well as children } \\
\text { under } 14 .\end{array}$ & $\begin{array}{c}\text { Affectation } \\
\text { level of PFP: } \\
\text { HBS. } \\
\text { Disability } \\
\text { induced by } \\
\text { PFP (physical } \\
\text { and social): } \\
\text { FDI. } \\
\text { Quality of life: } \\
\text { SF-36. }\end{array}$ & $\begin{array}{l}\text { Quality of } \\
\text { life in } \\
\text { patients with } \\
\text { PFP: FaCE. }\end{array}$ & $\begin{array}{c}\text { Patiens with PFP suffer from a } \\
\text { severe social and psychological } \\
\text { disability. } \\
\text { Patients with chronic PFP } \\
\text { showed a greater disability than } \\
\text { patients with acute PFP. Female } \\
\text { an older patients showed more } \\
\text { social and psychological } \\
\text { disability }\end{array}$ \\
\hline $\begin{array}{l}\text { Togni et al. } \\
\quad(2016)\end{array}$ & $\begin{array}{l}\text { Cross- } \\
\text { sectional } \\
\text { study }\end{array}$ & $\begin{array}{c}\mathrm{N}=61 \\
41(\mathrm{~W}) ; 20(\mathrm{M}) \\
\text { Age: } 49,7(\mathrm{SD}= \\
13,92)\end{array}$ & - & - & 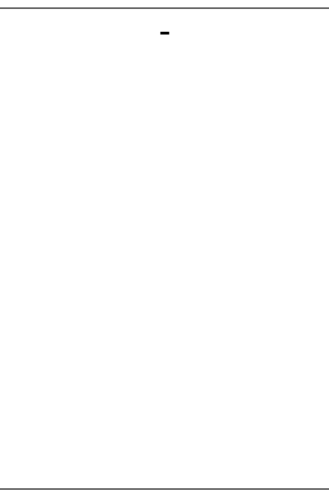 & $\begin{array}{l}\text { Affectation } \\
\text { level of PFP: } \\
\text { FGS. } \\
\text { Facial } \\
\text { disability } \\
\text { level: FDI. } \\
\text { Temper and } \\
\text { character: } \\
\text { TCI. }\end{array}$ & $\begin{array}{l}\text { Depression: } \\
\text { BDI. }\end{array}$ & $\begin{array}{l}\text { Personality features modulate } \\
\text { facial paralysis disability. Self- } \\
\text { management shows up to } \\
\text { mediate between the facial } \\
\text { paralysis and the disability. } \\
\text { Understanding how personality } \\
\text { features influence in disability } \\
\text { perception can be useful to } \\
\text { inprove the relationship between } \\
\text { the doctor and the patient and to } \\
\text { allow personalized and effective } \\
\text { therapeutic interventions }\end{array}$ \\
\hline $\begin{array}{l}\text { Pouwels et al. } \\
\text { (2014) }\end{array}$ & $\begin{array}{c}\text { Cross- } \\
\text { sectional }\end{array}$ & $\begin{array}{c}\mathrm{N}=59 \\
\text { Age }=18-75\end{array}$ & $\begin{array}{c}\mathrm{N}=59 \\
\text { Randomly }\end{array}$ & - & $\begin{array}{l}\text { PFP diagnostic, good } \\
\text { level of german. }\end{array}$ & - & $\begin{array}{l}\text { Anxiety and } \\
\text { depressive }\end{array}$ & $\begin{array}{l}\text { Significant differences have } \\
\text { been found in anxiety and }\end{array}$ \\
\hline
\end{tabular}




\begin{tabular}{|c|c|c|c|c|c|c|c|c|}
\hline & study & $\begin{array}{l}\text { Affectation: } \\
28 \text { PF left } \\
30 \text { PF right }\end{array}$ & $\begin{array}{c}\text { chosen, } \\
\text { without } \\
\text { previous } \\
\text { PF } \\
\text { symptoms, } \\
\text { psychiatric } \\
\text { or } \\
\text { psychologi } \\
\text { cal }\end{array}$ & & & & $\begin{array}{l}\text { sympthoms: } \\
\text { HADS. }\end{array}$ & $\begin{array}{l}\text { depression between FP patients } \\
\text { and healthy controls. Clinically } \\
\text { significant differences have not } \\
\text { been found in the presence of } \\
\text { anxiety or depressive symphons } \\
\text { between right or left PFP. }\end{array}$ \\
\hline $\begin{array}{c}\text { Worrack et al. } \\
\text { (2018) }\end{array}$ & $\begin{array}{l}\text { Cross- } \\
\text { sectional } \\
\text { study }\end{array}$ & $\mathrm{N}=81$ & - & - & - & $\begin{array}{c}\text { PFP } \\
\text { sympthons } \\
\text { and sleep } \\
\text { evaluation: } \\
\text { PSQI } \\
\text { Quality of life: } \\
\text { SF-36. }\end{array}$ & $\begin{array}{l}\text { Depression: } \\
\text { PHQ9. } \\
\text { Social } \\
\text { Anxiety: } \\
\text { LSAS. }\end{array}$ & $\begin{array}{c}\text { Facial changes related to PFP } \\
\text { causes psychological problems } \\
\text { that lead to reduccion in sleep } \\
\text { quality. }\end{array}$ \\
\hline $\begin{array}{l}\text { Sun et al. } \\
\text { (2015) }\end{array}$ & $\begin{array}{l}\text { Cross- } \\
\text { sectional } \\
\text { study }\end{array}$ & $\begin{array}{c}\mathrm{N}=21 \\
11(\mathrm{M}) ; 10(\mathrm{~W}) \\
\text { Age: } 23-67\end{array}$ & - & - & $\begin{array}{l}\text { All the patients werw } \\
\text { diagnosed with } \\
\text { acoustic neuroma and } \\
\text { the surgery was made } \\
\text { by the same doctor in } \\
\text { all cases. }\end{array}$ & $\begin{array}{l}\text { Level of } \\
\text { Affectation of } \\
\text { PF: HBS and } \\
\text { Burres- } \\
\text { Fisch. } \\
\text { Quality of life: } \\
\text { SF-36. } \\
\text { Questionary of } \\
\text { post-surgery } \\
\text { perceptions. }\end{array}$ & $\begin{array}{l}\text { Anxiety: } \\
\text { SAS. } \\
\text { Autoreporte } \\
\text { d } \\
\text { depression: } \\
\text { SDS. }\end{array}$ & $\begin{array}{l}\text { The PFP caused by the } \\
\text { treatment of microsurgery can } \\
\text { provoke psychological } \\
\text { sympthomps. }\end{array}$ \\
\hline $\begin{array}{l}\text { VanSwearing } \\
\text { en et al. } \\
\text { (1998) }\end{array}$ & $\begin{array}{l}\text { Cross- } \\
\text { sectional } \\
\text { study }\end{array}$ & $\begin{array}{c}\mathrm{N}=48 \\
\text { Age: } 49(18-48) \\
(\mathrm{SD}=16,3)\end{array}$ & - & - & $\begin{array}{l}\text { Older than } 18 . \\
\text { Had to be part of the } \\
\text { facial center of } \\
\text { Pittsburgh University. }\end{array}$ & $\begin{array}{l}\text { Affectation } \\
\text { level of PFP: } \\
\text { FGS. } \\
\text { Facial } \\
\text { disablity level: } \\
\text { FDI. Subscale } \\
\text { of physical } \\
\text { and social } \\
\text { wellness. }\end{array}$ & $\begin{array}{l}\text { Depresión: } \\
\text { BDI. }\end{array}$ & $\begin{array}{l}\text { In this study of relations } \\
\text { between clinical variables in } \\
\text { facial neuromotor disorders, the } \\
\text { facial deterioration was related } \\
\text { with physical and social } \\
\text { disability, wtih psychological } \\
\text { disorders that stress the impact } \\
\text { in fisical and psychological } \\
\text { disability and are conected with } \\
\text { the social disability. }\end{array}$ \\
\hline $\begin{array}{l}\text { VanSwearing } \\
\text { en et al. } \\
\text { (1999) }\end{array}$ & $\begin{array}{l}\text { Cross- } \\
\text { sectional } \\
\text { study }\end{array}$ & $\begin{array}{c}\mathrm{N}=29 \\
\text { Age: } 50,2(18- \\
81)\end{array}$ & - & - & - & $\begin{array}{c}\text { Facial } \\
\text { disability level } \\
\text { : FDI. }\end{array}$ & $\begin{array}{c}\text { Depression: } \\
\text { BDI. }\end{array}$ & $\begin{array}{l}\text { The smile and physical } \\
\text { disability were the main } \\
\text { predictors of depression in }\end{array}$ \\
\hline
\end{tabular}




\begin{tabular}{|c|c|c|c|c|c|c|c|c|}
\hline & & (SD: 17,0) & & & & $\begin{array}{l}\text { Measure of } \\
\text { facial } \\
\text { movement: } \\
\text { MSRA. } \\
\text { Highest static } \\
\text { response, a } \\
\text { quantitive } \\
\text { measurement } \\
\text { of } \\
\text { deterioration,a } \\
\text { uto- } \\
\text { notification } \\
\text { rate, especific } \\
\text { from the } \\
\text { región of } \\
\text { social and } \\
\text { physical } \\
\text { disability, } \\
\text { related to } \\
\text { facial } \\
\text { deterioration. }\end{array}$ & & $\begin{array}{l}\text { patients of neuromuscular facial } \\
\text { conditions.Global deterioration } \\
\text { of facial movement was not a } \\
\text { main predictor. }\end{array}$ \\
\hline $\begin{array}{l}\text { Lee et al. } \\
(2007)\end{array}$ & $\begin{array}{l}\text { Cross- } \\
\text { sectional } \\
\text { study }\end{array}$ & $\begin{array}{c}\mathrm{N}=56 \\
30(\mathrm{M}) ; 26(\mathrm{~W}) \\
\text { Age: } 54,9 \\
\text { (SD: } 1,7)\end{array}$ & - & - & $\begin{array}{l}\text { All the patients spoke } \\
\text { english. Nobody with } \\
\text { facial pathology } \\
\text { previous to surgery. }\end{array}$ & $\begin{array}{l}\text { Affectation } \\
\text { PFP level: } \\
\text { HBS. }\end{array}$ & $\begin{array}{l}\text { Quality of } \\
\text { life in } \\
\text { patients with } \\
\text { PFP: FaCE. }\end{array}$ & $\begin{array}{l}\text { This impact magnitude in } \\
\text { quailty of life can be not } \\
\text { predicted by the severity of } \\
\text { facial paralysis, the age or the } \\
\text { gender of the patient, the time } \\
\text { passed since the surgery or the } \\
\text { size of the tumour. }\end{array}$ \\
\hline $\begin{array}{l}\text { Lindsay et al. } \\
\qquad(2014)\end{array}$ & $\begin{array}{l}\text { Cross- } \\
\text { sectional } \\
\text { study }\end{array}$ & $\mathrm{N}=148$ & - & - & Patients with PFP. & $\begin{array}{l}\text { Facial } \\
\text { evaluation by } \\
\text { Software: } \\
\text { FACE-gram. }\end{array}$ & $\begin{array}{l}\text { Quality of } \\
\text { life in } \\
\text { patients with } \\
\text { PFP: FaCE. }\end{array}$ & $\begin{array}{c}\text { The treatment of gracilis muscle } \\
\text { produces and increase of the } \\
\text { quality of life in patients with } \\
\text { PF. }\end{array}$ \\
\hline $\begin{array}{l}\text { Walker et al. } \\
\text { (2012) }\end{array}$ & $\begin{array}{l}\text { Cross- } \\
\text { sectional } \\
\text { study }\end{array}$ & $\begin{array}{c}\mathrm{N}=126(2 \\
\text { women for each } \\
\text { man) } \\
\text { Age: } 50,1(17- \\
93)\end{array}$ & - & - & $\begin{array}{l}\text { Patients with PFP } \\
\text { older than } 16 .\end{array}$ & - & $\begin{array}{l}\text { Anxiety and } \\
\text { depression: } \\
\text { HADS. }\end{array}$ & $\begin{array}{l}\text { The severity of the paralysis is } \\
\text { what affects to the } \\
\text { psychological wellness of the } \\
\text { patient and not the presents of } \\
\text { the pathology. }\end{array}$ \\
\hline $\begin{array}{l}\text { Weir et al. } \\
\text { (1995) }\end{array}$ & $\begin{array}{c}\text { Cross- } \\
\text { sectional }\end{array}$ & $\begin{array}{c}\mathrm{N}=20 \\
12(\mathrm{~W}) ; 8(\mathrm{M})\end{array}$ & - & $\begin{array}{l}6 \text { days from } \\
\text { PFP }-7 \text { years }\end{array}$ & $\begin{array}{l}\text { Patients with } \\
\text { idiopathic PFP. }\end{array}$ & $\begin{array}{l}\text { Perception of } \\
\text { the self-image: }\end{array}$ & $\begin{array}{l}\text { Anxiety and } \\
\text { depression: }\end{array}$ & $\begin{array}{c}\text { Increase in anxiety an } \\
\text { depression levels. }\end{array}$ \\
\hline
\end{tabular}




\begin{tabular}{|c|c|c|c|c|c|c|c|c|}
\hline & study & Age: $41(15-78)$ & & $\begin{array}{c}\text { (average of } 65 \\
\text { days). }\end{array}$ & & $\begin{array}{c}\text { FSI. } \\
\text { General health } \\
\text { state: GHQ. } \\
\text { Functional } \\
\text { disability: } \\
\text { FDQ. }\end{array}$ & $\begin{array}{l}\text { part of } \\
\text { GHQ. }\end{array}$ & \\
\hline $\begin{array}{l}\text { Silva et al. } \\
\text { (2011) }\end{array}$ & $\begin{array}{l}\text { Case-control } \\
\text { study }\end{array}$ & $\begin{array}{c}\mathrm{N}=16 \\
5(\mathrm{M}) ; 11(\mathrm{~W}) \\
\text { Age: } 43-48 \\
\text { PFP phase: } 4 \\
\text { flaccid, } 6 \\
\text { recovery y } 6 \\
\text { sequel }\end{array}$ & - & - & $\begin{array}{c}\text { Patients with } \\
\text { idiopathic PFP older } \\
\text { than 18. Patients with } \\
\text { traumatic PFP are } \\
\text { excluded. }\end{array}$ & $\begin{array}{l}\text { PFP phase: } \\
\text { otorhinolaryng } \\
\text { ologic and } \\
\text { speech- } \\
\text { language } \\
\text { exam. } \\
\text { Severity level } \\
\text { of PFP: HBS. }\end{array}$ & $\begin{array}{l}\text { Psychosocial } \\
\text { variables: } \\
\text { open } \\
\text { interview. }\end{array}$ & $\begin{array}{l}\text { Patients with PFP in an } \\
\text { aftermath phase presented a } \\
\text { greater affectation in } \\
\text { psychosocial ways followed by } \\
\text { those who were in a flaccid and } \\
\text { recovery phase. }\end{array}$ \\
\hline $\begin{array}{l}\text { Goines et al. } \\
\text { (2016) }\end{array}$ & $\begin{array}{l}\text { Case-control } \\
\text { study }\end{array}$ & $\mathrm{N}=16$ & $\begin{array}{c}\mathrm{N}=4 \\
\mathrm{~N}=84 \\
\text { observers } \\
59(\mathrm{~W}) \\
25(\mathrm{M})\end{array}$ & - & $\begin{array}{l}\text { Older than } 18, \\
\text { without autism nor } \\
\text { schizophrenia. }\end{array}$ & $\begin{array}{c}\text { Facial clinic } \\
\text { rating scale, } \\
\text { quality of life, } \\
\text { the paralysis } \\
\text { severity and } \\
\text { the disability } \\
\text { were } \\
\text { evaluated by a } \\
\text { visual } \\
\text { analogical } 100 \\
\text { points scale. }\end{array}$ & $\begin{array}{l}\text { Effective } \\
\text { balance: } \\
\text { ABS } \\
\text { (happy, } \\
\text { content, } \\
\text { vigorous, } \\
\text { affectionate, } \\
\text { anxious, } \\
\text { depressed, } \\
\text { guilty and } \\
\text { hostile). }\end{array}$ & $\begin{array}{l}\text { The observers rated with a less } \\
\text { quality of life in patients that } \\
\text { presented facial paralysis in } \\
\text { comparison to the self-reported } \\
\text { disability by the patients. }\end{array}$ \\
\hline
\end{tabular}

2 PFP: peripheral facial paralysis; M: man; W: woman; SD: standard deviation; FGS: Sunnybrook Facial Grading System; HADS:

3 Hospital Anxiety and Depression Scale; FDI: Facial Disability Index; FaCE: Facial Clinimetric Evaluation; FPEM: Facial Paralysis

4 Evaluation Profile; GBI: Glasgow Befefit Inventory; IPQ-R: Illness Perception Questionnaire-Revised; HBS: House-Brackmann Scale;

5 BDI: Beck Depression Inventory; FAIR: Facial Nerve Palsy Integration Register; VAS = Visual Analogue Scale; TCI:

6 Temperament and Character Inventory; SAS: Self-assessment Anxiety Scale, SDS: Self-assessessed Depression Scale; ABS: Affect

7 Balance Scale; SDS: Zung Self-Rating Depression Scale; FSI: Facial Self-Image Scale; FDQ: Funcional Disability Questionnaire; GHQ: 
8 General Health Questionnaire; MSRA: Measerement of Facial Motion; LSAS: Liebowitz Social Anxiety Scale; PHQ9: Patient Health 9 Questionaire. 
Table 2 (on next page)

Quality assessment of cross-sectional studies.

$\mathrm{S}=$ selection $; \mathrm{C}=$ comparability $; \mathrm{O}=$ outcome 
1 Table 2. Quality assesment of cross-sectional studies.

\begin{tabular}{|c|c|c|c|c|c|c|c|c|c|c|c|}
\hline $\begin{array}{c}\text { Cross-sectional } \\
\text { studies }\end{array}$ & $\begin{array}{c}\text { S1: } \\
\text { Representativeness } \\
\text { of the exposed } \\
\text { cohort }\end{array}$ & $\begin{array}{c}\text { S2: } \\
\text { Selection } \\
\text { of the } \\
\text { non- } \\
\text { exposed } \\
\text { cohort }\end{array}$ & $\begin{array}{c}\text { S3: } \\
\text { Ascertainment } \\
\text { of exposure }\end{array}$ & $\begin{array}{c}\text { S4: } \\
\text { Demonstration } \\
\text { that outcome } \\
\text { of interest was } \\
\text { not present at } \\
\text { the start of the } \\
\text { study } \\
\end{array}$ & $\begin{array}{l}\text { C1a: } \\
\text { Study } \\
\text { controls } \\
\text { for } \\
\text { previous } \\
\text { injury }\end{array}$ & $\begin{array}{l}\text { C1b: } \\
\text { Study } \\
\text { controld } \\
\text { for age }\end{array}$ & $\begin{array}{c}\text { O1: } \\
\text { Assessment } \\
\text { of outcome }\end{array}$ & $\begin{array}{l}\text { O2: Follow- } \\
\text { up long } \\
\text { enoght for } \\
\text { outcomes to } \\
\text { occur }\end{array}$ & $\begin{array}{c}\text { O3: } \\
\text { Adecuacy } \\
\text { of follow up } \\
\text { of cohorts }\end{array}$ & Total & $\%$ \\
\hline $\begin{array}{c}\text { Díaz-Aristizabal } \\
\text { et al. (2019) }\end{array}$ & & - & $\star$ & - & - & - & & - & - & $1 / 3$ & 33 \\
\hline $\begin{array}{c}\text { Bradbury et al. } \\
\qquad(2006)\end{array}$ & & - & $\star$ & - & - & - & & - & - & $1 / 3$ & 33 \\
\hline $\begin{array}{l}\text { Coulson et al. } \\
\text { (2004) }\end{array}$ & & - & $\star$ & - & - & - & & - & - & $1 / 3$ & 33 \\
\hline $\begin{array}{c}\text { Fu et al. (2011) } \\
\text { Muhammad }\end{array}$ & & - & $\star$ & - & - & - & & - & - & $1 / 3$ & 33 \\
\hline $\begin{array}{l}\text { Kassim et al. } \\
\text { (2019) }\end{array}$ & & - & $\star$ & - & - & - & & - & - & $1 / 3$ & 33 \\
\hline $\begin{array}{l}\text { Nellis et al. } \\
\text { (2017) }\end{array}$ & & - & $\star$ & - & - & - & & - & - & $1 / 3$ & 33 \\
\hline $\begin{array}{l}\text { Kleiss et al. } \\
\text { (2015) }\end{array}$ & & - & $\star$ & - & - & - & & - & - & $1 / 3$ & 33 \\
\hline $\begin{array}{l}\text { Volk et al. } \\
\text { (2017) }\end{array}$ & & - & $\star$ & - & - & - & & - & - & $1 / 3$ & 33 \\
\hline $\begin{array}{l}\text { Togni et al. } \\
\text { (2016) }\end{array}$ & & - & $\star$ & - & - & - & & - & - & $1 / 3$ & 33 \\
\hline $\begin{array}{l}\text { Pouwels et al. } \\
\text { (2014) }\end{array}$ & & - & $\star$ & - & - & - & & - & - & $1 / 3$ & 33 \\
\hline $\begin{array}{l}\text { Worrack et al. } \\
\qquad(2018)\end{array}$ & & - & $\star$ & - & - & - & & - & - & $1 / 3$ & 33 \\
\hline Sun et al. (2015) & & - & $\star$ & - & - & - & & - & - & $1 / 3$ & 33 \\
\hline \multirow[t]{2}{*}{$\begin{array}{l}\text { VanSwearingen } \\
\text { et al. (1998) }\end{array}$} & & - & $\star$ & - & - & - & & - & - & $1 / 3$ & 33 \\
\hline & & - & $\star$ & - & - & - & & - & - & $1 / 3$ & 33 \\
\hline
\end{tabular}




\begin{tabular}{|c|c|c|c|c|c|c|c|c|c|}
\hline \multicolumn{10}{|l|}{$\begin{array}{c}\text { VanSwearingen } \\
\text { et al. (1999) }\end{array}$} \\
\hline Lee et al. (2007) & - & $\star$ & - & - & - & - & - & $1 / 3$ & 33 \\
\hline $\begin{array}{l}\text { Lindsay et al. } \\
\text { (2014) }\end{array}$ & - & $\star$ & - & - & - & - & - & $1 / 3$ & 33 \\
\hline $\begin{array}{l}\text { Walker et al. } \\
\text { (2012) }\end{array}$ & - & $\star$ & - & - & - & - & - & $1 / 3$ & 33 \\
\hline $\begin{array}{c}\text { Weir et al. } \\
\text { (1995) }\end{array}$ & - & $\star$ & - & - & - & - & - & $1 / 3$ & 33 \\
\hline \multicolumn{10}{|l|}{2} \\
\hline \multicolumn{10}{|c|}{3} \\
\hline \multicolumn{10}{|c|}{$4 \mathrm{~S}=$ selection $; \mathrm{C}=$ comparability $; \mathrm{O}=$ outcome } \\
\hline \multicolumn{10}{|l|}{5} \\
\hline
\end{tabular}




\section{Table 3(on next page)}

Quality assessment of case studies and controls.

$\mathrm{S}=$ selection $; \mathrm{C}=$ comparability $; \mathrm{E}=$ Exposure 
1 Table 3. Quality assesment of case studies and controls.

\begin{tabular}{|c|c|c|c|c|c|c|c|c|c|c|c|}
\hline $\begin{array}{c}\text { Case- } \\
\text { Contro } \\
\quad 1 \\
\text { Studies }\end{array}$ & $\begin{array}{c}\text { S1: } \\
\text { Definitio } \\
\text { n of the } \\
\text { cases }\end{array}$ & $\begin{array}{c}\text { S2: } \\
\text { Representativine } \\
\text { ss of the cases }\end{array}$ & $\begin{array}{c}\text { S3: } \\
\text { Selectio } \\
\text { n of } \\
\text { controls }\end{array}$ & $\begin{array}{c}\text { S4: } \\
\text { Definitio } \\
\text { n of } \\
\text { controls }\end{array}$ & $\begin{array}{c}\text { C1a: } \\
\text { Study } \\
\text { controls } \\
\text { for } \\
\text { previou } \\
\text { s injury }\end{array}$ & $\begin{array}{c}\text { C1b: } \\
\text { Study } \\
\text { control } \\
\text { s for } \\
\text { age }\end{array}$ & $\begin{array}{c}\text { E1: } \\
\text { Ascertainme } \\
\text { t of } \\
\text { exposure }\end{array}$ & $\begin{array}{c}\text { E2: Same } \\
\text { method of } \\
\text { ascertainmen } \\
\text { t for cases } \\
\text { and controls }\end{array}$ & $\begin{array}{c}\text { E3: } \\
\text { Non- } \\
\text { respons } \\
\text { e rate }\end{array}$ & $\begin{array}{c}\text { Tota } \\
\mathbf{l}\end{array}$ & $\%$ \\
\hline $\begin{array}{l}\text { Silva et } \\
\text { al. } \\
(2011)\end{array}$ & $\star$ & & $\star$ & $\star$ & $\star$ & $\star$ & $\star$ & & & $6 / 9$ & $\begin{array}{l}6 \\
7\end{array}$ \\
\hline $\begin{array}{l}\text { Goines } \\
\text { et al. } \\
(2016)\end{array}$ & $\star$ & & $\star$ & $\star$ & $\star$ & $\star$ & $\star$ & & & $6 / 9$ & $\begin{array}{l}6 \\
7\end{array}$ \\
\hline
\end{tabular}

$3 \mathrm{~S}=$ selection; $\mathrm{C}=$ comparability $; \mathrm{E}=$ Exposure 
